\title{
A new technique of pulmonary hernia surgical repair using intramedullary titanium implants
}

\author{
Szymon Wcisło, Marcin Wawrzycki, Piotr Misiak, Marian Brocki \\ Department of Thoracic Surgery, General Surgery and Oncology, Medical University of Lodz, Poland
}

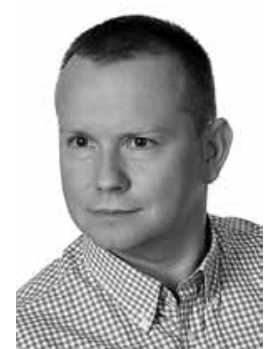

Kardiochirurgia i Torakochirurgia Polska 2015; 12 (1): 26-29

\begin{abstract}
Introduction: In this paper we present a new method of pulmonary hernia surgical treatment. Pulmonary hernia is a rare pathology. The first description of pulmonary hernia was made by Roland in 1499. The world literature describes only a little more than 300 cases of pulmonary hernia. Pulmonary hernia is defined as the projection of the lung tissue covered by the parietal pleura beyond the normal boundaries of the pleural cavity, through the pathological holes in the chest wall. During our work as thoracic surgeons, we have used different ways of thoracic chest wall reconstructive operations and anastomoses of the broken ribs.

Aim of the study: To search for optimal methods of pulmonary hernia surgery and to evaluate a new technique of pulmonary hernia surgical repair using intramedullary titanium implants. Material and methods: In 2013 in our clinic, we diagnosed and cured two patients with idiopathic pulmonary hernia. We performed a reconstructive operation of the chest wall with anastomosis of the broken ribs using titanium intramedullary stabilization implants - splints.

Results: To date, the annual observation has revealed no recurrence of pulmonary hernia or postoperative complications. At present, the patients demonstrate full life activity.

Conclusions: So far, in the world literature, we have not encountered any information about using such methods to repair pulmonary hernia. We regard our method as safe, easy to use and giving good therapeutic results.
\end{abstract}

Key words: lung hernia, intramedullary titanium implant, splint.

\section{Introduction}

Pulmonary hernia is a rare pathology. The first description of pulmonary hernia was made by Roland in 1499 [1]. In 1847, Morel-Lavallée created the first classification of pulmonary hernia. He divided the disorder into two groups: congenital (18\%) and acquired, which was split into two subgroups, the first being post-traumatic hernia (52\%) and the second comprising idiopathic and pathological hernias

\section{Streszczenie}

Wstęp: W pracy zaprezentowano nową metodę chirurgicznego leczenia przepukliny płucnej - rzadkiej patologii opisanej po raz pierwszy przez Rolanda w 1499 roku. Światowa literatura opisuje jedynie niewiele ponad 300 przypadków tego schorzenia. Przepuklina płucna definiowana jest jako przemieszczenie się tkanki płucnej pokrytej opłucną ścienną poza prawidłowe granice jamy opłucnej przez patologiczne otwory w ścianie klatki piersiowej. Przeprowadzając zabiegi torakochirurgiczne, autorzy korzystali z różnych metod rekonstrukcji ściany klatki piersiowej i naprawy złamanych żeber.

Celem pracy było poszukiwanie optymalnych metod chirurgicznego leczenia przepukliny płucnej oraz ocena nowej techniki chirurgicznego zaopatrzenia przepukliny płucnej z wykorzystaniem tytanowych implantów wewnątrzszpikowych.

Materiał i metody: W 2013 roku autorzy zdiagnozowali i wyleczyli w klinice dwóch pacjentów z samoistną przepukliną płucną. Wykonano zabiegi rekonstrukcji klatki piersiowej wraz z naprawą złamanych żeber, wykorzystując tytanowe wewnątrzszpikowe implanty stabilizacyjne - splinty.

Wyniki: Roczna obserwacja nie wykazała nawrotu choroby ani powikłań pooperacyjnych. Pacjenci przejawiają obecnie pełną aktywność życiową.

Wnioski: Autorzy nie znaleźli żadnych wzmianek w światowej literaturze dotyczących wykorzystania opisanych w pracy metod naprawy przepukliny płucnej. Uważają opisaną metodę za bezpieczną, łatwą w zastosowaniu i terapeutycznie skuteczną. Słowa kluczowe: przepuklina płucna, tytanowy implant wewnątrzszpikowy, splint.

(30\%). The classification is shown in Table I [2]. Another classification of pulmonary hernia was created based on its anatomical location; here, we distinguish cervical and thoracic hernia. The world literature describes only a little more than 300 cases of pulmonary hernia [3]. Pulmonary hernia is defined as the projection of the lung tissue covered by the parietal pleura beyond the normal boundaries of the pleural cavity, through the pathological holes in the

Address for correspondence: Szymon Wcisło, MD, Department of Thoracic Surgery, General Surgery and Oncology, Medical University of Lodz, 55G/25 Romanowska St., 91-174 Lodz, Poland, phone: +48 509725 545, e-mail: szwcislo@gmail.com 
Tab. I. Classification of pulmonary hernia

\begin{tabular}{|c|c|c|c|}
\hline \multicolumn{2}{|l|}{ Type } & Cause & Frequency \\
\hline \multicolumn{2}{|l|}{ Congenital } & Rib or intercostal muscles agenesis or hypoplasia & $18 \%$ \\
\hline \multirow{2}{*}{ Acquired } & Post-traumatic & $\begin{array}{l}\text { Blunt injuries, e.g. motor-vehicle accidents } \\
\text { Rib fractures } \\
\text { Thoracotomy } \\
\text { Cardiopulmonary resuscitation }\end{array}$ & $52 \%$ \\
\hline & Spontaneous and pathological & $\begin{array}{c}\text { Cough } \\
\text { Chronic obstructive pulmonary disease (COPD) } \\
\text { Permanent steroid therapy }\end{array}$ & $30 \%$ \\
\hline
\end{tabular}

chest wall $[4,5]$. The best method for diagnosis of pulmonary hernia is computed tomography [6]. Conservative treatment and observation are recommended in patients with small hernias without clinical symptoms. Large pulmonary hernias producing clinical symptoms require surgical treatment. The world literature describes the methods of surgical treatment of such hernias, from closure of the ring of hernia by moving the intercostal spaces closer using surgical sutures, applying polypropylene nets or the patient's own tissues such as the fascia of the latissimus dorsi or flaps of the chest wall muscles [3, 7, 8]. In 2009, Wiens et al. described a new technique of the surgical treatment of pulmonary hernia using laminar hooks connected to titanium bars that are fixed to the ribs with modified hooks. The materials and surgical techniques applied by these authors are used by neurosurgeons in the correction of spinal injuries and scoliosis [9]. Using the information and experience of surgeons who previously treated pulmonary hernia and described their conclusions in the literature, we performed reconstructive operations of pulmonary hernia in two patients using intramedullary titanium implants (splints).

\section{Material and methods}

In 2013, at the Department of Thoracic Surgery, General Surgery and Oncology, we diagnosed two patients with

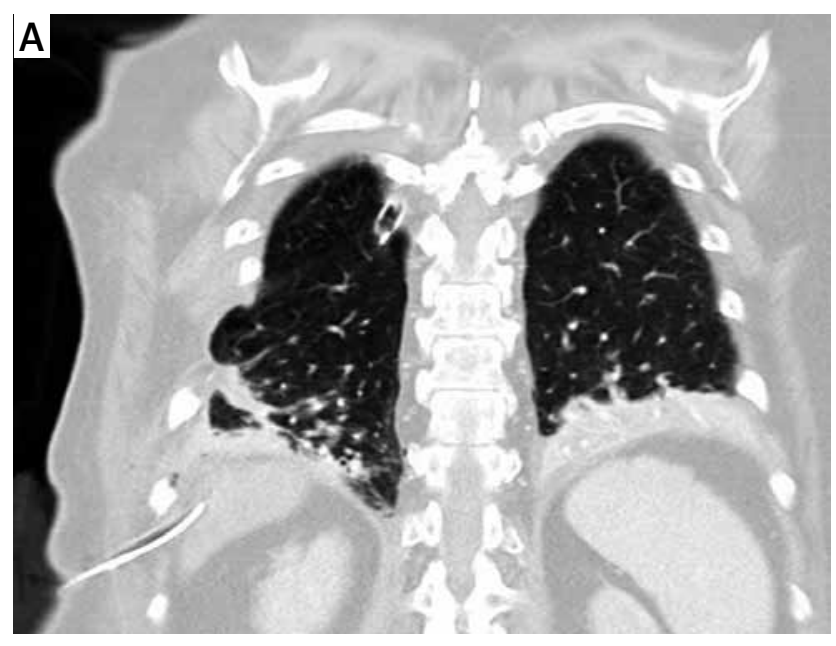

idiopathic pulmonary hernia. The medical history of both patients ruled out chest injuries as the cause of pulmonary hernia. The diagnostic imaging confirmed rib fractures in both patients with formation of the hernial ring (Fig. 1A, B). In both cases, hernia produced the signs of pain on breathing and in one patient it caused the recurrent presence of fluid in the pleural cavity with accompanying shortness of breath. In both patients, 3D computed tomography performed before the scheduled surgery clearly depicted rib fractures (Fig. 2). Fractures were located in the posterolateral portion of the ribs (from 6 to 10). Due to the nature of idiopathic fracture, we did the test for osteoporosis and osteopaenia. The diseases were excluded in both cases. Accordingly, the two patients were qualified for a reconstructive operation of the chest wall using intramedullary titanium implants (splints) designed to repair rib fracture. The procedure was performed under general anaesthesia with a double lumen endotracheal tube with independent lung ventilation. The surgical incision of the chest was performed centrally, over the palpable ring of hernia. The hernial sac was reached and opened (Fig. 3). In both cases, there were no adhesions between the lung and the chest wall. The excess of the hernial sac was resected together with the parietal pleura. The dislocated rib fractures were located. The rib fractures were set and a hole was made

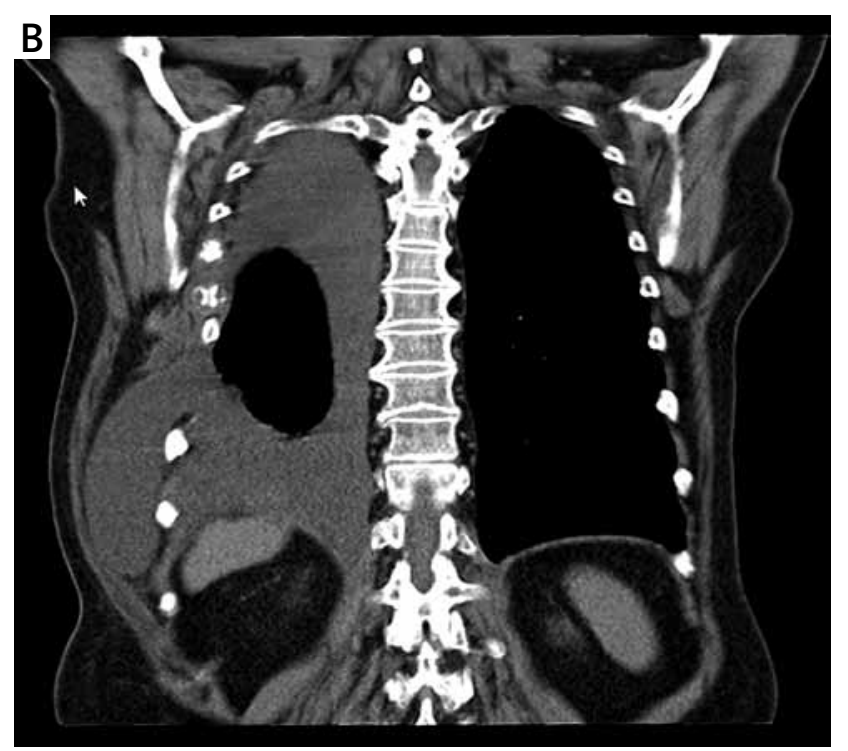

Fig. 1. Computed tomography scan - pulmonary hernia 


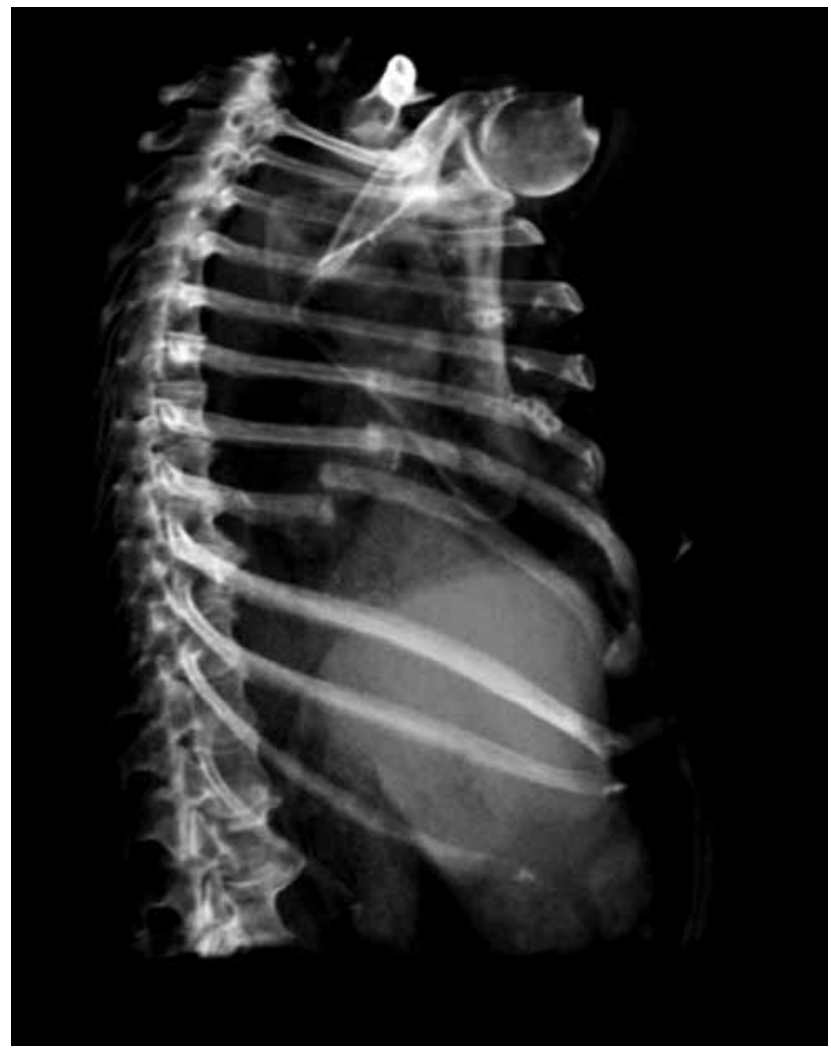

Fig. 2. 3D computed tomography scan - rib fractures

in the anterior wall of the rib using surgical tools such as a drill and screwdriver. The holes were made in the proximal ends of the ribs and used to insert a splint. It was directed to the marrow cavity towards the vertebral column (Fig. 4). A splint was fixed to the proximal part of the rib using a titanium screw. After stabilization of the ribs using splints, extra holes were drilled in the neighbouring ribs and the formed openings were additionally stabilized with the help of surgical sutures (Fig. 5). Additional drilling of the ribs decreased the pressure exerted by surgical stitches on the intercostal nerves. In the annual postoperative observation, this action directly reduced the postoperative

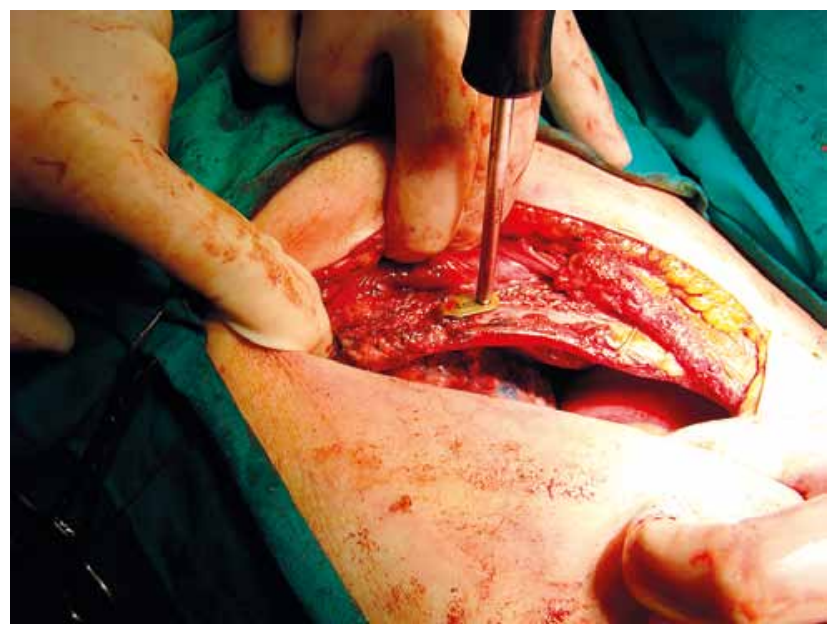

Fig. 4. Titanium implants insertion - intraoperative image

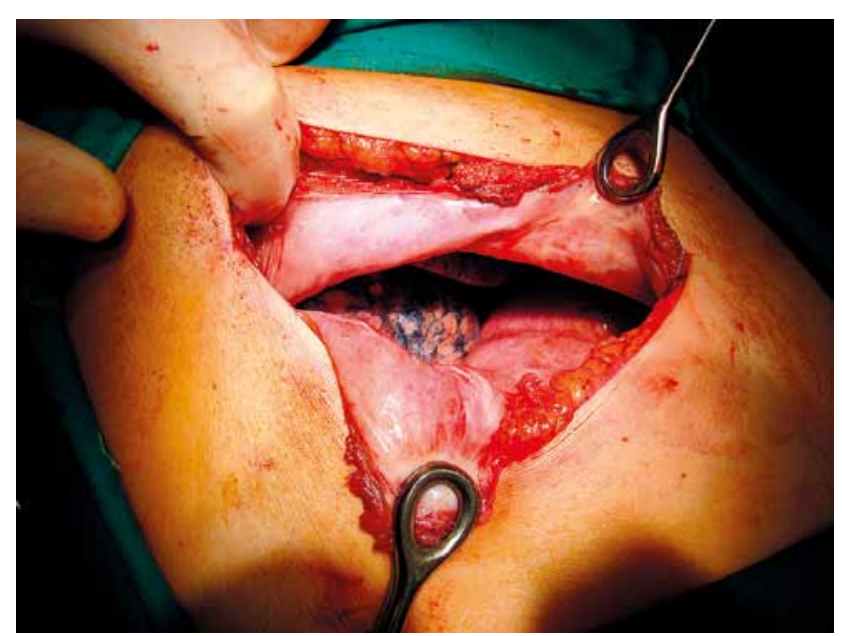

Fig. 3. Hernial sac - intraoperative image

pain. The treatments ended with the typical insertion of a drain into the pleural cavity. The chest wall was closed by stitching the muscles, subcutaneous tissue and skin. On the second day after surgery, the drains were removed from the pleural cavity. The patients were discharged home on the fourth and fifth day after the surgery. The patients remain under the constant control of our thoracic surgery out-patient clinic. To date, the annual observation has revealed no recurrence of pulmonary hernia or postoperative complications. Every three months, we perform imaging studies such as computed tomography and X-ray. The location of the implanted splints is correct (Fig. 6). After the surgery, the first patient required the temporary use of analgesics for the first two months. He had no recurrence of the fluid in the pleural cavity or shortness of breath; the second patient used painkillers also in the case of pain during the first month. At present, the patients demonstrate full life activity.

\section{Conclusions}

The world literature describes numerous methods of pulmonary hernia treatment, from simply moving the ribs

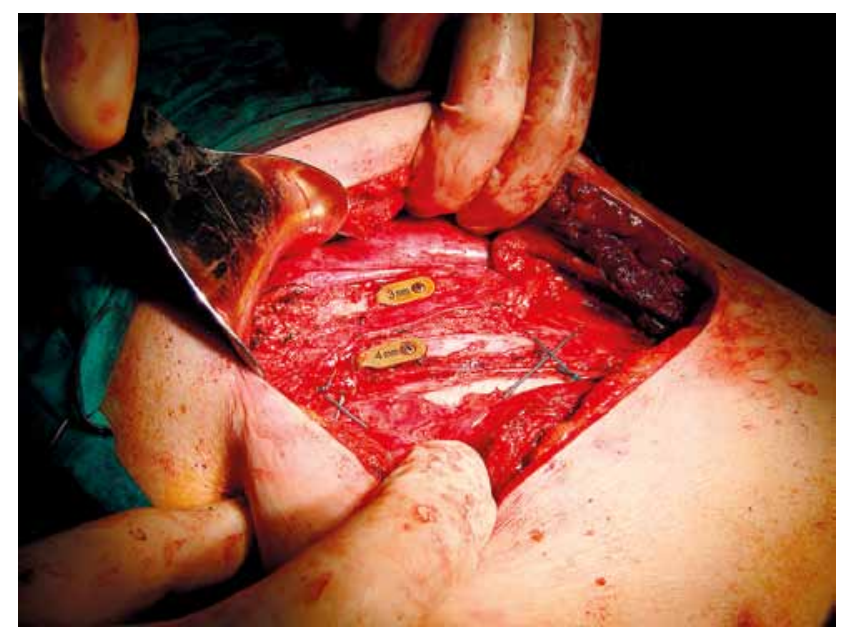

Fig. 5. Final result - intraoperative image of stabilisation with titanium implants and surgical sutures 


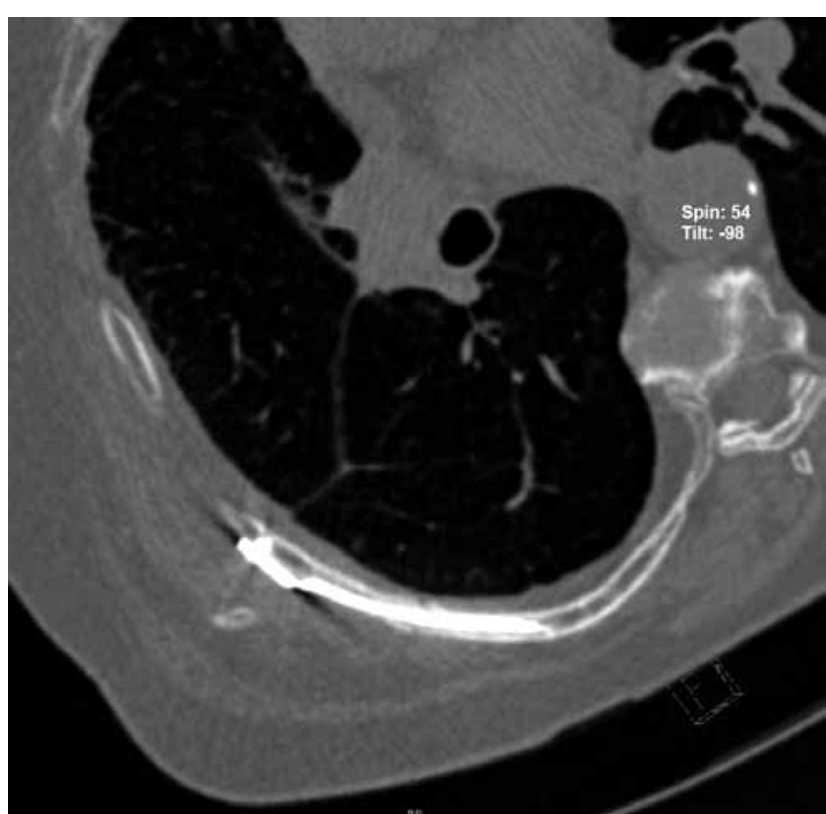

Fig. 6. Computed tomography scan - correct location of the implanted titanium implants

closer using surgical sutures, through the use of nets and muscle flaps to support the ring of hernia [3, 8]. In 2009, a report on the use of neurosurgical methods and materials for the treatment of pulmonary hernia was published [9]. Due to the fact that patients expect a full return to active life, stable scaffolding of the chest wall and proper functioning of the respiratory system, there is still a search for optimal methods of pulmonary hernia surgery. The use of intramedullary titanium implants ensures reliable sta- bilization of the chest wall and no sensation of implants being palpable under the skin. In combination with the additional rib stitches placed through the extra holes, which additionally move the ribs closer, we have obtained more stabilization and reduced postoperative pain. The annual observation revealed no complications in patients operated on using this technique. If we have at our disposal the titanium implants necessary for the fixation of broken ribs, our method of surgical treatment of large and symptomatic pulmonary hernia is a simple procedure. It is also safe and meets the expectations of both patients and doctors for the surgical treatment of pulmonary hernia.

\section{Disclosure}

Authors report no conflict of interest.

\section{References}

1. Montgomery JG, Lutz H. Hernia of the lung. Ann Surg 1925; 82: 220-231.

2. Morel-Lavallée A. Hernies du poumon. Bull Soc Chir Paris 1847; 1: 75.

3. Weissberg D, Refaely Y. Hernia of the lung. Ann Thorac Surg 2002; 74: 1963 1966.

4. Bhalla M, Leitman BS, Forcade C, Stern E, Naidich DP, McCauley DI. Lung hernia: radiographic features. AJR Am J Roentgenol 1990; 154: 51-53.

5. Maurer E, Blades B. Hernia of the lung. J Thorac Surg 1946; 15: 77-98.

6. Sadler MA, Shapiro RS, Wagreich J, Halton K, Hecht A. CT diagnosis of acquired intercostal lung herniation. Clin Imaging 1997; 21: 104-106.

7. Arslanian A, Oliaro A, Donati G, Filosso PL. Posttraumatic pulmonary hernia. I Thorac Cardiovasc Surg 2001; 122: 619-621.

8. Ross RT, Burnett CM. Atraumatic lung hernia. Ann Thorac Surg 1999; 67: 1496-1497.

9. Wiens S, Hunt I, Mahood J, Valji A, Steward K, Bedard ELR. Novel fixation technique for the surgical repair of lung hernia. Ann Thorac Surg 2009; 88: 1034-1035. 